\title{
Küçük Hâfız Mustafa Efendi’nin Sofyalı Süleyman Rüsûhî’nin şiirine yazdığı şerh: Şerh-i Kasîde-i Rüsûhî
}

\section{Erdoğan TAŞTAN 1}

\begin{abstract}
APA: Taştan, E. (2020). Küçük Hâfız Mustafa Efendi’nin Sofyalı Süleyman Rüsûhî’nin şiirine yazdığı şerh: Şerh-i Kasîde-i Rüsûhî Turkey. RumeliDE Dil ve Edebiyat Araştırmaları Dergisi, (Ö7), 439-454. DOI: 10.29000/rumelide.813406
\end{abstract}

\section{$\ddot{O} \mathbf{z}$}

18. yüzyıl müelliflerinden biri olan Küçük Hâfız Mustafa Efendi (ö.1728-29'dan sonra) hakkında biyografik kaynaklarda herhangi bir bilgi bulunmamaktadır. Onun hakkında bildiklerimiz Nüzhetü'l-'uşşâk adlı eserinde kaydedilenlerle sınırlıdır. Bu bilgilere göre müellifin, Sultan III. Ahmed (salt. 1703-1730) devrinde Enderun'un Seferli Koğuşu'nda eğitim gördüğü, burada vaktinin çoğunu ilim öğrenmekle geçirdiği ve sonraki yıllarda da Enderun'dan ayrıldığı anlaşılmaktadır. Hayatında zaman zaman geçim sıkıntı da çeken müellifin şerh türünde yazılmış Nüzhetü’l-‘şşâk ve Şerh-i Kasîde-i Rüsûhî adlı iki eseri mevcuttur. Bu eserlerden ilki, Sofyalı Süleymân Rüsûhî (ö.?)'nin 13 beyitten meydana gelen “-ā nedir” kafiye ve redifli şiirindeki bir beyti, ikincisi ise aynı şiirin diğer beyitlerini şerh etmek amacıyla yazılmıştır. Bu çalışmanın konusunu teşkil eden Şerh- $i$ Kasîde-i Rüsûhî, müellifin diğer eserine göre muhtasar bir şerh özelliği göstermektedir. Öyle ki Rüsûhî’nin bazı tasavvufi sualleri ihtiva eden şiirindeki beyitlerin birkaçı sadece birkaç cümle ile şerh edilmiştir. Bazı beyitlerin şerhinde ise müellifin açıklamayı geniş tuttuğu, farklı kaynaklardan alıntılarla konuyu teferruatıyla ele aldığı görülür. Eserde "esmâ, sıfât, akl-ı evvel, Ruh-ı Muhammedî, Kelime-i Tevhîd, şirk, îmân, kaza, kader, insan-ı kâmil ve insanın diğer varlıklardan üstün oluşu” gibi çeşitli konuların ele alındığı görülmektedir. Âyet ve hadis iktibaslarıyla da zenginleştirilen şerh, orta nesir türünde yazılmış bir eser olarak değerlendirilebilir.

Anahtar kelimeler: 18. yy., Küçük Hâfız Mustafa Efendi, Süleymân Rüsûhî, şerh, tasavvuf

\section{The commentary that Küçük Hâfiz Mustafa Efendi wrote on the poem of Süleyman Rüsûhî from Sofia: Şerh-i Kasîde-İ Rüsûhî}

\begin{abstract}
There is no information in biographical sources about Küçük Hafiz Mustafa Efendi (d.?), one of the $18^{\text {th }}$ century authors. What we know about him is limited to what is recorded in his work named Nüzhetü'l-'uşşâk. According to this information, the author was educated in Enderun in Seferli Koğuşu, where he spent most of his time learning science during the reign of Ahmed III (r. 17031730) and left Enderun in the following years. There are two works of the author who sometimes had difficulties in his life, named Nüzhetü'l-'uşşâk and Şerh-i Kasîde-i Rüsûhî, written in the style of commentary. The first of these works is written to comment a couplet in the poem of Süleymân Rüsûhî which consist of 13 couplets and has the word "nedir" as rhyme, and the second is written to comment the other couplets of the same poem. Şerh-i Kasîde-i Rüsûhî, which constitutes the subject of this study, shows a concise commentary feature compared to the other work of the author. So much so that a few of the couplets in Rüsûhî's poem, which contains some mystical

Dr. Öğr. Üyesi, Marmara Üniversitesi, Atatürk Eğitim Fakültesi, Türkçe ve Sosyal Bilimler Eğitim Bölümü (İstanbul, Türkiye), etastan39@gmail.com, ORCID ID: 000o-0002-2348-5632 [Makale kaytt tarihi: 22.09.2020-kabul tarihi: 20.10.2020; DOI: 10.29000/rumelide.813406]
\end{abstract}




\begin{abstract}
questions, were annotated with only a few sentences. In the commentary of some couplets, it is seen that the author kept the explanation wide and discussed the subject in detail with quotations from different sources. In the work, it is seen that various subjects such as "esmâ, sifât, the wisdom, RûhI Muhammedî, the Word of the Tawheed, polytheism, the faith, the destiny and superiority of man to other beings " are discussed. The commentary enriched by the quotations of verses and hadiths can be regarded as a work written in the middle prose type.
\end{abstract}

Keywords: $18^{\text {th }}$ century, Küçük Hâfiz Mustafa Efendi, Süleymân Rüsûhî, commentary, mysticism

\title{
Giriş
}

Çeşitli sahalarda kaleme alınan eserler üzerine yazılan ve temelde bu eserleri açıklama, onlarda bulunan anlaşılması müşkül bazı kelime, kavram, ibare, cümle, mısra veya beyitleri anlaşılır kılma amacı taşıyan şerh türündeki eserler, edebiyatımızda güçlü bir şerh geleneğinin teşekkülünü de beraberinde getirmiştir.

Geçen asırlar boyunca temel hadis ve fikıh kitapları, akâidle ilgili eserler, esmâ-i hüsnâ ve dua mecmuaları, hilye-i nebîler gibi çok sayıda dinî eserin yanında, dil, gramer, astronomi, tıp, fizik, aritmetik ve geometri gibi çeşitli sahalarda kaleme alınmış eserlerin de şerh edildiği görülür. (Ceylan 2000: 20,24). Bunların yanında klâsik edebî ve tasavvufi eserlerin de şerh geleneği içinde önemli bir yer teşkil ettiği göze çarpar. Hâfız-ı Şîrâzî (ö.1390?), Şevket-i Buhârî (ö.1696), Sẩib-i Tebrîzî (ö.1670?), Örfî-i Şîrâzî (ö.1591), İbni Fârız (ö.1235), Molla Câmî (ö.1492) gibi şairlerin divanlarına veya seçilmiş bazı şiirlerine yapılan şerhlerle birlikte Mesnevî, Bostan, Gülistân, Bahâristân, Mantıku't-tayr, Pendnâme-i Attâr, Şebistân-ı Hayâl, Fusûsu'l-hikem, Muhammediye, Gülşen-i Râz, Delâ’ilül-hayrât gibi edebî yönü yanında dinî, tasavvufi ve ahlaki özelliği de bulunan eserlerin şerhleri, bazı aşk mesnevileriyle tarihî-destani ve menkıbevi mesnevilerin şerhleri, Tuhfe-i Şâhidî, Tuhfe-i Vehbî, Nuhbe-i Vehbî, Sübha-i Sibyân gibi lügatlere yapılmış şerhler, çeşitli şairlere ait kaside, gazel, muammâ, lügaz, dü-beyt gibi nazım şekil ve türlerindeki eserler için yazılmış şerhler, bu şerhlerden bazılarıdır (Yllmaz 2007: 271-304; Yazar 2011: 263-640, 679-710).

Yukarıda bahsi geçen şerhlere ek olarak Yunus Emre (ö.1320?), Niyâzî-i Mısrî (ö.1694), Ümmî Sinan (ö.1657), Hacı Bayram-ı Velî (ö.1430), Eşrefoğlu Rûmî (ö.1469-70?), Dede Ömer Rûşenî (ö.1487), İsmâîl Hakkî-i Bursevî (ö.1725), Sun'ullâh-ı Gaybî ( ö. 1676'dan sonra) gibi tasavvuf büyüklerinin gazel, kaside, şathiyye gibi şiirlerine yazılan ve çeşitli tasavvufî öğretileri konu alan şerhler de şerh geleneği içinde önemli bir yere sahiptir (Ceylan 2000: 34-65; Yazar 2011: 641-678). Kelime-i Tevhid, şerî̀ hükümler, miraç, melekler, şeytan, kıyamet, cennet, cehennem, âşık, ma'şûk, zâhid, rind, câm, mey gibi dinî ve tasavvufi konuların yanında tefsir, hadis, fikıh, kelam, hikmet, kîmya, tıp, sarf, nahiv, belâgat, peygamber kıssaları, önemli mutasavvıfların menkıbeleri gibi farklı meselelere de yer veren bu tür tasavvufi şiir şerhleri, muhtevalarının zenginliği bakımından şerh geleneği açısından önemli birer kaynak hükmündedirler (Ceylan 2000: 121-413). Bu çalışmanın konusunu oluşturan Sofyalı Süleymân Rüsûhî (ö.?)'nin şiirine Küçük Hâfız Mustafa Efendi (ö.1728-29'dan sonra) tarafından yapılan şerh de bu tür şerhlerden biridir.

Bu yazıda önce söz konusu şiiri şerheden Küçük Hâfız Mustafa Efendi'nin hayatı ve eserleri hakkında bilgi verilecek, sonra müellifin Şerh-i Kasîde-i Rüsûhî adlı eseri incelenip söz konusu şerhin metni aktarlacaktır. 


\section{Küçük Hâfız Mustafa Efendi ve eserleri}

Biyografik kaynaklarda hakkında herhangi bir bilgiye rastlayamadığımız Küçük Hâfız Mustafa Efendi ile ilgili bildiklerimiz, Süleymaniye Kütüphanesi Ali Nihat Tarlan Bölümü 137/1 numarada (34 SüTarlan 137/1) kayıtlı Nüzhetü'l-'uşşâk adlı eserinde yer alan malumattan öteye geçmez. Müellif, bu eserin sebeb-i telîf bölümünde kendisi ile ilgili olarak şu ifadelere yer vermektedir: Bu kitāb-ı

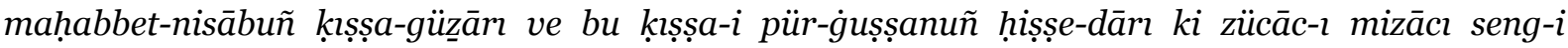
mușībet ile şikeste ve zahm-ı g gamze-i cānān ile bīmār ü haste, nār-ı firāk ile sūzān ve bār-ı iftirāk ile

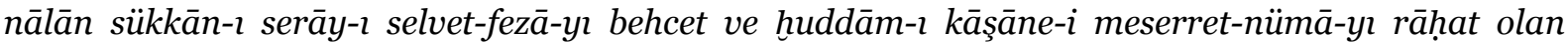

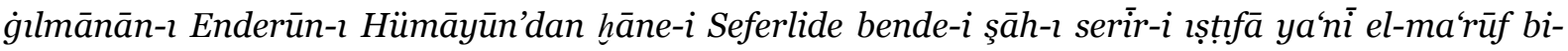

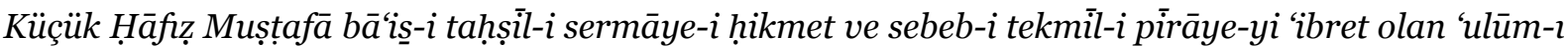

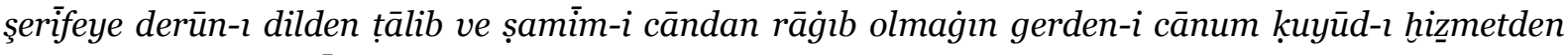

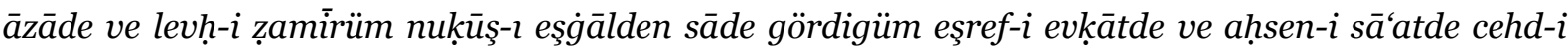
belïg ve sa'y-i bi-dirig eylerdüm (34 Sü-Tarlan 137/1, 3b-4a). Bu bilgilere ek olarak yazmanın zahriyesinde de müellifin biyografisine katkı sağlayacak olan şu kayıt yer almaktadır: Bĩ̃ yüz ḳrk bir senesinde İstanbul'a varduḳda şevketli pādişāh-ı 'ālem Sulțān Aḥmed Hān Hażretlerinüñ Seferli

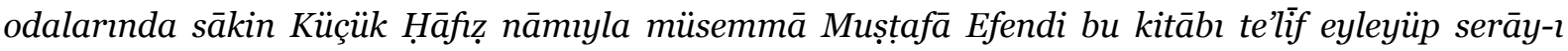
hümāyūndan bu faḳire ihdā eyledükde kenārinda olan tārīhn tạ̣rīr olunup ba'dehü Sulțān Aḥmed Cāmi'innüñ imāmetiyle çlḳup Yūsuf Efendi-zāde'den Beyżāvì dersine şerīk olmışdurur, Nüzhetü’l'uşşāḳ nāmiyla müsemmādur (34 Sü-Tarlan 137/1, 1a).

Bu bilgilerden hareketle Küçük Hâfız Mustafa Efendi'nin Sultan III. Ahmed (salt. 1703-1730) devrinde Enderun-ı Hümâyûn'un Seferli Koğuşu'nda eğitim gördüğü, 1141/1728-29 yllında Nüzhetü’l-'uşşâk adlı eserini yazdığı ve Enderun'da bulunduğu dönemde ilme rağbet edip ilim öğrenmekle meşgul olduğu için, koğuştaki diğer hizmetlerden ve meşguliyetlerden âzâde olduğu anlaşılmaktadır. Yukarıdaki kayda göre Sultan Ahmed Camii'nin imamlığı vazifesiyle Enderun'dan ayrılan müellif, dedesine nisbetle Yûsuf Efendizâde diye anılan Abdullah Hilmî (ö.1754)'nin Beyzâvî derslerine katılmıştır. Yine

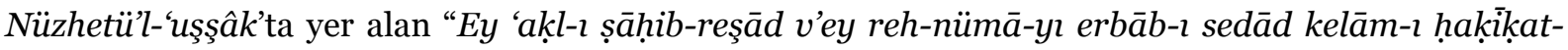

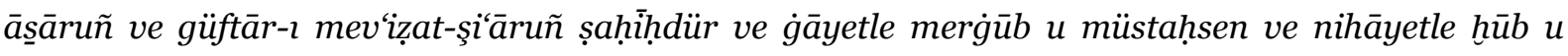
rūşendür. Lākin bu bende-i ednā ve çāker-i bì-riyā eyyām-ı șabāveti ve hengām-ı hadāșeti henūz tecāvüz eyleyüp ser-ḥadd-i 'işrīne bālig olmış bir țfl-ı ebced-ḩvānam (34 Sü-Tarlan 137/1, 12b)." şeklindeki ifadelere göre müellif bu eserini oldukça genç bir yaşta, henüz yirmili yaşlarının başındayken kaleme almıştır. Eserin muhtevasını ve eser hazırlanırken faydalanılan kaynakları değerlendirdiğimizde müellifin genç yaşına rağmen geniş bir bilgi birikimine sahip, iyi yetişmiş biri olduğunu, temel dinî, tasavvufi ve edebî kaynaklara vâkıf bulunduğunu söyleyebiliriz. Nüzhetü'l-'uşşâk için yazılmış ve eserin başına kaydedilmiş olan tarih manzumeleri ve takrizlerde müellifin övgüsü sadedinde söylenen sözler de bu durumu destekler mahiyettedir.

Nüzhetü'l-'uşşâk'ın bulunduğu 34 Sü-Tarlan 137/1 numaralı yazmanın en başında da müellifin biyografisiyle ilgili bazı bilgilerin ve kendisine ait bir şiirin kaydediliği göze çarpar. Burada, yukarıdaki bilgileri teyit eden cümlelerden sonra şu kaydın ve ardından müellife ait aşağıdaki şiirin yer aldığı görülür: Lākin terḳim-i mahall-i merkūm istīlā-yı aṣhāab-ı düyūn-ı pederiyye[ye] müṣādefe étmekle

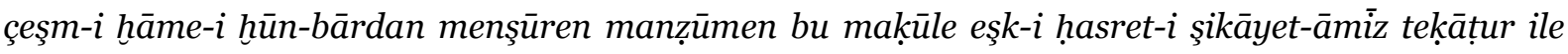
düşdi: 
The commentary that Küçük Hâfiz Mustafa Efendi wrote on the poem of Süleyman Rüsûhî from Sofia: Şerh-i Kasîde-i Rüsûhî / E. Taştan (pp. 439-454)

\author{
[Fe‘ilātün féilātün fe‘ilātün fe‘ilün] \\ Yüridi kāfile-i rehzen-i mașraf yine āh \\ Ḳıllet-i ceyş-i 'avā'id ile ḥāl ise tebāh \\ Nafaḳa kisve vü süknā ise elbet lāzım \\ Tutalum yétmiş aña ‘ā’ide-i her bir māh \\ Aḳrabā vü müte‘allı̣̣laruñ aḥvāli yaman \\ Çekerek mā-meleki cümle alurlar her gāh \\ Göre erbāb-ı ḥuḳūḳuñ hele istīlāsın \\ $\mathrm{Ne}$ 'aceb miḥnet ile geçdi bu 'ömrüm eyvāh \\ Ṭāli' -i bedle hemān keşmekeş olmaḳda işüm \\ Ne zamān ref'-i nikāàb étse gerek baḩt-ı siyāh \\ Ḥāfıẓā böyle ḳalursa ḳatı düşvār aḥvāl \\ Meger ỉrāda meded eyleye Fettāḥ Allāh \\ (34 Sü-Tarlan 137/1, Ib)
}

Bu bilgilerden ve müellife ait yukarıdaki şiirden hareketle Küçük Hâfız Mustafa Efendi’nin geçim sıkıntısı çektiği, maddi imkânsızlıklarla boğuşup babasından kalan borçları da ödemek zorunda kaldığı söylenebilir. Nitekim Nüzhetü'l-'uşşâk'ın çeşitli yerlerinde de hayatındaki zorluk ve sıkıntılardan bahsetmesi, onun rahat bir ömür sürmediği şeklinde yorumlanmalıdır. Bu bilgiler haricinde müellifin nereli olduğu, doğum ve vefat tarihleri, ailesi, eğitiminin detayları gibi bilgilere maalesef şu an için vâkıf değiliz.

Elimizdeki bilgilere göre Küçük Hâfız Mustafa Efendi’nin birbiriyle muhteva bakımından bağlantılı olan iki eseri mevcuttur. Bunlardan ilki Sofyalı Süleymân Rüsûhî̀nin "-ā nedir” kafiye ve redifli şiirindeki bir beytin şerhine dayanan Nüzhetü’l-'uşşâk, diğeri de bu şiirin diğer beyitlerini şerh etmek amacıyla yazdığı Şerh-i Kasîde-i Rüsûhî adlı eserleridir.

\title{
1-) Nüzhetü'l-'uşşâk:
}

Küçük Hâfiz Mustafa Efendi’nin 16. yüzyll şairi Sofyalı Süleyman Rüsûhî̀ye ait “-ā nedir” kafiye ve redifli gazelin yedinci beyti olan

‘Āşıḳa ma'şūḳ artıḳ rāğıb iken pes yine

Anda bu deñlü temennā bunda istiğnā nedür

şeklindeki beyti şerh etmek amacıyla 1141/1728-29 yllında telif ettiği eserdir. Eserine diğer klâsik eserlerde olduğu gibi Allah'a hamd ve övgü içeren ifadelerle başlayan müellif, sonrasında ilk olarak Hz. Peygamber’i ardından dört halifeyi öven cümlelerle devam eder. Giriş mahiyetindeki bu bölümden

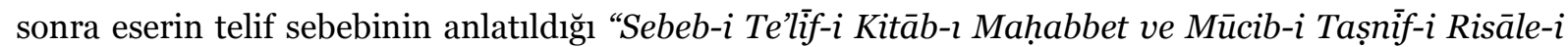
Mịnnet” başlıklı bölüm gelir. Bu bölümde müellif adını söyleyip Enderun'un Seferli Koğuşu’nda bulunduğunu, burada ilim öğrenmeye rağbet edip bu yolda elinden geldiği kadar çalıştığını, zaman 
zaman zevk-i selim sahibi dostlarıyla sohbet meclisleri kurup hoşça vakit geçirdiğini belirttikten sonra yirmi otuz kişinin aynı anda vefat ettiği ve kendisini derinden sarsan bir hadiseden bahseder. Henüz bu hadisenin tesirinden kurtulamamışken çok sevdiği ve "sebeb-i vücûd-ı bî-sûdum olan pîr ki..." diye başlayarak kendisinden sitayişle bahsettiği bir zâtın vefatıyla yıkılan müellif adeta matem havasına büründüğünü ve çok gözyaşı dökerek derinden sarsıldığını belirtir. Ancak "bir şeyh-i kerâmet-penâh ve 'ârif-i pür-intibâh" olarak nitelediği birinin, ölümün herkesin başına geleceği ve ondan kaçış olmadığı, kazaya rızadan gayrı derman ve belaya sabırdan başka imkân bulunmadığı yolundaki nasihatları üzerine başına gelenlere boyun eğip rıza gösterdiğini ve böylece kendine geldiğini söyler. Tekrar ilme ve kitaplara yönelen müellif, rastgele eline aldığı bir mecmuada "metâ'-ı belâgatın hvâce-i cihânı ve vasf-ı fesâhatın bedî̌ü’l-beyânı ” olarak nitelediği Sofyalı Süleyman Rüsûhî’nin

Ey ki ‘ālemden haber-dārum déyen dünyā nedür

mısraı ile başlayan kasidesini bir kişinin baştan sona şerh ettiğini, ancak

‘Āşıḳa ma‘şūḳ artık rāğıb iken pes yine

Anda bu deñlü temennā bunda istignnā nedür

beytine geldiğinde bunu görmezden gelerek şerh etmekten kaçındığını belirtir. Söz konusu beyti şerhe karar veren müellif yaşının oldukça genç olması dolayısıyla hakkıyla bu işin üstesinden gelemeyeceği ve başkaları tarafından eleştirileceği endişesiyle bir an tereddüt gösterse de nihayetinde şerhe giriştiğini ve kısa bir zamanda da bitirdiğini ifade eder.

Küçük Hâfız Mustafa Efendi, sebeb-i telîf bölümünden sonra, âyet ve hadisler yanında İmâm-ı Gâzalî (ö.1111), Firûzâbâdî (ö.1415), Molla Câmî (ö.1492), Fuzûlî (ö. 1556) gibi şahsiyetlerin eserlerinden de faydalanarak söz konusu beyti şerhe başlar. Eserin ilerleyen kısımlarında aşkın çeşitli özelliklerinin ele

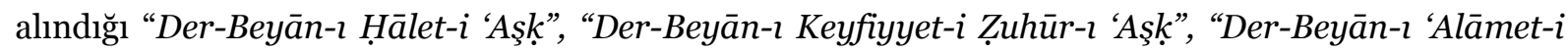

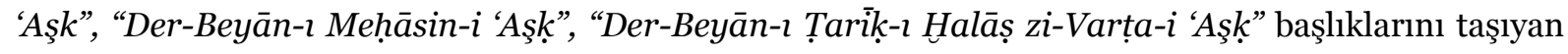
beş bölüm yer alır ve eser bu şekilde sona erer.

Şu anki bilgilerimize göre elimizde Nüzhetü’l-‘uşsâk'ın tek nüshası mevcuttur. Süleymaniye Kütüphanesi Ali Nihat Tarlan Bölümü 137/1 numarada kayıtlı bu nüsha, 101 varaktan meydana gelen bir yazmanın 1b-89a varakları arasında yer almaktadır. 220x152-138x66 mm ölçülerindeki yazma sırtı meşin, esmere yakın sarı, mukavva kapaklı bir cilt içindedir. Talik hatla yazılan yazmanın her sayfasında 13 satır vardır. Yazmanın başında Sofyalı Süleyman Rüsûhînnin Kınalızâde Hasan Çelebi Tezkiresi'nde yer alan biyografisi ve Küçük Hâfız Mustafa Efendi'ye ait yukarıda yer alan bazı bilgilerle bir şiiri yer almaktadır.

Yazmada bundan sonra Nüzhetü’l-'uşşâk için kaleme alınmış üç takriz ve iki tarih manzumesiyle müellif hakkında yazılmış bir kıt‘a yer alır. Takrizlerden ilki Şeyh Muhammed bin Mîrzâde Muhammed el-Kâdî tarafından Arapça olarak kaleme alınmıştır. İkincisi Yûsuf Efendizâde diye anılan Abdullâh Hilmî (ö.1754) tarafından yine Arapça olarak yazılmıştır. Üçüncü takriz ise Abdu’r-rahmân el-Hâkî el-Aynî tarafından Türkçe olarak kaleme alınmıştır. Eser için yazılan tarih manzumelerinin ilki yine Aynî tarafından yazılan ve kendisine ait takrizden sonra kaydedilmiş bulunan beş beyitlik Arapça şiirdir. İkinci tarih manzumesi ise Nu'mân Sâbit bin Hamdî-i Sivasî (ö.1768) tarafından Türkçe olarak kaleme alınmış olup yedi beyitten meydana gelmektedir. Bu manzume şu şekildedir: 


\section{Tārih-i Nu'mān Șābit bin Ḥamdīi Sīvāsī Berāy-ı Te’līf-i Ḥāfı̣ Muṣtafā Efendi Der-Serāy- 1 Hümāyūn}

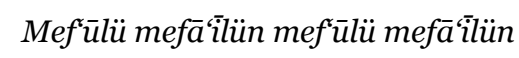

Ol Ḥāııẓ-ı rūşen-dil hem-nām-ı cihān fahrı

Deryā-yı hıred içre cānā dür-i yektādur

‘İlm ü hüner-i 'irfān meşrūța olup aña

Bu tekye-i ‘ālemde bir mürşid-i vālādur

Her fenn-i ma‘ārifde tefsīir-i ma‘ānìde

Ol zāât-1 hüner-perver çün mecma'-1 deryādur

'Işḳı édüp ol ta'rīf tāze bir eșer étdi

Iẓhārı bu te'lífi ḩalḳa Yed-i Beyżā’dur

Bu nüshayı kim görse étmez nice șad taḥsīn

Şāyeste-i maḳbūli ḥaḳkāa ülüll-ārādur

Bu S̄ābit-i Sīvāsī gördükde bu āsāāı

Șad ed'iyyeler ile tārīhine gūyādur

Bir düşdi cihān içre bu te'līfe tārīhüm

Gülzār-ı ma‘ārifde bu bir gül-i zỉbādur

(1141/1728-29)

Bu tarih manzumesinden sonra yine Nu'mân Sâbit bin Hamdî-i Sivasî̀ye ait müellif övgüsünde yazılan aşağıdaki kıt‘a yer alır:

\section{Kuț'a}

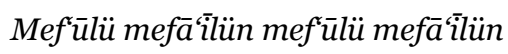

Ey kān-ı ma‘ārif sen luṭfuñı ferāvān ét

Ol nüsḩa-i tesvidi bu dāiiye iḥsān ét

Mesrūr-ı fu'ād eyle bu S̄ābit'i şād eyle

Bu muhlıṣı yād eyle ğıbța-keş-i aḳrān ét

Bu bölümlerin ardından gelen 1a sayfası, yazmanın zahriyesidir. Bu sayfada müellif hakkında yukarıda bahsi geçen bilgileri ihtiva eden kısa bir bölümle vakıf kaydının bulunduğu görülür. Yazmanın 1b varağında da Nüzhetü’l-'uşşâk başlar.

\section{2. Şerh-i Kasîde-i Rüsûhî:}

Küçük Hâfız Mustafa Efendi’nin diğer eseri, Rüsûhînnin "-ā nedir” kafiye ve redifli şiirini şerh için yazdığı eserdir. Müellif, bu şiirin

‘Āşıḳa ma‘şūḳ artık rāğıb iken pes yine

Anda bu deñlü temennā bunda istignnā nedür 
şeklindeki beytini şerh etmek amacıyla Nüzhetü'l-‘uşşâk'ı yazdıktan sonra geri kalan beyitleri de şerh etme gereği duyarak bu eseri telif etmiş olmalıdır. Nüzhetü’l-‘uşşâk'a göre daha kısa olan bu şerhde şiirin mahlas beytinin de şerh edilmediği görülür.

Aslında müellife ait eserlerden hangisinin daha önce yazıldığı konusunda bir belirsizlik mevcuttur. Nüzhetül-'uşşâk'ın telif sebebinin anlatıldığı bölümdeki ifadeleri dikkate alacak olursak müellif, Süleyman Rüsûhî'nin şiirini ve bu şiirin başka bir şârih tarafından bir beyti eksik bırakılarak şerh edildiğini ilk gördüğü anda şerhi eksik olan beyti şerh etmeye karar vermiştir ve bundan önce gerek şiirden gerekse onun şerhinden habersiz olmalıdır. Üstelik bu eseri oldukça genç bir yaşta, yirmili yaşlarının başında telif etmiştir. Ancak Şerh-i Kasîde-i Rüsûhı̂nin İstanbul Büyükşehir Belediyesi Atatürk Kitaplığı OE Yz 684/1 numarada kayıtlı nüshasının sonunda bulunan ve bu nüshanın 1130/1717-18 senesinde Dervîş Ahmed bin Muhammed el-Kâdirî tarafından istinsah edilmiş olduğunu gösteren kayda göre bu eser, 1141/1728-29 yllında telif edilen Nüzhetü'l-'uşşâk'tan yaklaşık 11 yl önce kaleme alınmıştır. Ancak bu durumda da yirmili yaşlarının başında Nüzhetü’l-‘uşşâk'ı telif ettiğini belirten müellifin Şerh-i Kaside-i Rüsûhî̀yi onlu yaşlarının başında yazmış olması gerekir ki bu da pek mümkün görünmemektedir. Öyle anlaşllyyor ki yeni bir belge veya bilgi ortaya çıkana kadar bu iki eserden hangisinin daha önce yazıldığı kesinliğe kavuşamayacaktır.

Süleyman Rüsûhî’nin şerhe konu olan şiiri 17. yüzyılda Âyînezâde Muhammed Şemseddin-i Sirozî (ö.1688-89) tarafindan da şerh edilmiştir. Âyînezâde'nin bu şerhi daha önce tarafımızdan yayımlanmıştı. Bu yayında hem söz konusu şiirin sehven Mesnevî şârihi İsmâîl Rüsûhî-i Ankaravî (ö.1631)'ye ait olarak gösterilmesi ile ilgili yanlışlık belgeleriyle birlikte düzeltilmiş hem de şiiri yazan Sofyalı Süleyman Rüsûhî hakkında etraflıca bilgi verilmişti (Taştan 2017: 317-322). Bu bilgileri, tekrar olmaması için buraya almaya gerek duymadık.

Âyînezâde'nin bu şiiri şerh etmiş olması, Nüzhetül'-uşşâk'ın yazılmasına sebep olan beyti şerh etmeden geçen ve adı zikredilmeyen şârihin o olabileceğini akla getirmektedir. Ancak Âyînezâde'nin şerhinde bu beyit, diğer beyitler gibi şerh edilmiştir ve bu şerh genel itibarıyla Küçük Hâfız Mustafa Efendi'nin bu çalışmaya konu olan şerhinden daha tafsilatlıdır (Taştan 2017: 328-343). Belki de Hâfız Mustafa Efendi, Âyînezâde'nin söz konusu beyti şerh ettiğini gördü, ancak bunu yetersiz olarak düşünüp şerh edilmeden geçildiği şeklinde yorumladı ve bu durumu kendi şerhinin telifine bir sebeb olarak değerlendirdi. Ancak durum böyle değilse Küçük Hâfız Mustafa Efendi’nin eline geçen şerh, kimliğini bilmediğimiz üçüncü bir kişi tarafından telif edilmiş olmalıdır ki bu da Rüsûhî’nin şiirinin gördüğü rağbeti ve farklı bir şârih tarafından telif edilmiş, şu an elimizde olmayan bir başka şerhin varlığını gösterir.

\section{Eserin ismi}

Eserin hiçbir nüshasında şerhe isim olabilecek bir başlık veya bir ibare yer almadığı gibi metnin içinde de müellif tarafından bu amaçla kullanılmış bir ifade veya ibareye rastlanmamaktadır. Ancak sadece Milli Kütüphane Yazmalar Koleksiyonu o6 Mil Yz A 2581/8 numarada kayıtlı nüshanın başında Kasîde-i Rüsûhî Efendi şeklinde bir başlık bulunmaktadır ki bunda da eserin bir şerh olduğuna delalet eden bir durum söz konusu değildir. Bu nüsha, katalogda ise Şerh-i Kasîde-i Rüsûhî Efendi şeklinde kaydedilmiştir. Biz de bu kaydı ve biraz da bu nüshadaki başlığı dikkate alarak -şiirin gerçekten bir kaside olup olmadığı yönündeki tereddüdü de bir kenara bırakıp- Küçük Hâfız Mustafa Efendi’nin bu şerhi için Şerh-i Kasîde-i Rüsûhî başlı̆̆ını/adını kullanmayı uygun bulduk. 


\section{Süleymân Rüsûhî’nin şerhe konu olan şiiri}

Rüsûhî’nin şiiri on üç beyitten oluşan ve "aa, ba, ca ...” şeklinde kafiyelenmiş bir şiirdir. Şiirin, Âyînezâde'nin şerhinde kullanılan nüshası ile Küçük Hâfız Mustafa Efendi'nin şerhinde kullanılan nüshası arasında birkaç kelimeyi geçmeyen farklar bulunduğu görülmektedir. Bazı müşkül sualleri ihtiva eden ve tasavvufî bir muhtevaya sahip olan şiir, bu çalışmaya konu olan şerh metninde şu şekildedir:

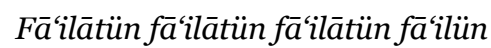
1. $\quad$ Ey ki ‘ālemden haber-dārum déyen dünyā nedür Bu günüñ yarını bilmezseñ déye dün yā nedür
2. On sekiz biñ 'ālemi garke eyleyen deryā nedür Yā o deryāyı yudan māhiçe-i ṣug̣rā nedür
3. $\quad \bar{A} d e m i$ tecrịh ü tercịh eyleyen kimler-dürür Kimden ihrāc étdiler İblīis'i istisnā nedür
4. Cins ü fașlı nev ü aṣlı bir iken ey bü'l-'aceb Arasında bunlaruñ bu deñlü bu ġavḡā nedür
5. Bunlaruñ hep feyzi bir yerden gelürken lā-cerem Kimi ‘ārif kimi 'āmī kimisi şeydā nedür
6. Kiminüñ huurşid-i ‘ālem zerre gelmez 'aynına Kimini her şeyde ḥayrān eyleyen āyā nedür
7. 'Āşı̣ka ma'şūk artıḳ rāğıb iken pes yine Anda bu deñlü temennā bunda istignā nedür
8. Şirk-ile ỉmān gelmez bir yere lā raybe fỉh Ehl-i İslām'uñ dilinde lā nedür illā nedür
9. Eyleyüp Ḥaḳ’’a tevekkül kul olan Mevlāsına Bugün içün gusșalanmaḳ yā gam-ı ferdā nedür
10. Söylemek görmek işitmek añlamaḳ bilmek nedür Yā bu evșāf ile mevșūf ol dür-i yektā nedür
11. Benden evvel bildügin étmiş éden olmış olan Bunda vü anda benümle olunan da'vā nedür
12. Hāme-i șun'a hațā nisbet olunmazsa eger Bunca yañlsşlar bu 'ālem defterinde yā nedür
13. Perde-i pindāruñ kạldırmayınca aradan
Ey Rüsūhỉi bilemezsüñ bunlara ma'nā nedür

\section{Şerhin tertip, muhteva ve üslûp özellikleri}

Küçük Hâfız Mustafa Efendi’nin bu eserde, klasik eserlerde karşılaştığımız tertip hususiyetlerine dikkat etmediğini, doğrudan beyitleri şerhe giriştiğini görürüz. Bu durum şerhin Nüzhetü’l-usş̧âk'a göre daha muhtasar bir şekilde ele almasından kaynaklanmış olmalıdır. Sözü fazla uzatmak istemeyen müellif, hemen beyitleri şerhe girişmiş olmalıdır.

Şerhin dikkat çeken özelliklerinden biri oldukça muhtasar bir şerh oluşudur. Birkaç beyit dışında müellif beyitlerin açıklamalarını kısa tutmuş, şiirin son beytini ve Nüzhetü'l-'uşşâk'da geniş bir şekilde ele aldığı için yedinci beytini şerh etmemiştir. Ancak

Benden evvel bildügin étmiş éden olmış olan

Bunda vü anda benümle olunan da'vā nedür 
şeklindeki beytin oldukça tafsilatlı bir biçimde şerh edilmiş olduğu da dikkati çeker.

Şerh, muhtasar olmasına rağmen içinde "esmâ ve sıfât, insân-ı kâmil, Âdem, İblis, melekler, iman, kazâ, kader, Kelime-i Tevhid, kendini bilen kişinin Rabb’ini de bileceği, insanın yaratılışı, irade, cebr, bugününü değerlendirmek ve yarın için endişe duymamak” gibi çeşitli konulara yer verildiği görülür.

Şerhin dikket çeken bir diğer özelliği, muhtasar bir şerh olmasına rağmen içinde oldukça fazla sayıda farklı kaynaklardan yapılmış iktibasların bulunmasıdır. Müellifin, konuyu daha iyi izah etmek için âyet, hadis, kelâm-ı kibâr iktibasları yanında Seyyid Nesîmî (ö.1417?), Hâfız-ı Şîrâzî (ö.139o?), Sa‘dî-i Şîrâzî (ö.1292), Ömer Hayyâm (ö.1132?), Nâsır-1 Tûsî (ö.1274) gibi şahsiyetlerin eserlerinden de iktibaslarda bulunduğu görülür.

Şerh-i Kasîde-i Rüsûhî, dil ve üslup olarak orta nesir türü eserler arasında değerlendirilebilir. Metinde Arapça ve Farsça kelime ve tamlamalara yer verilmiş olsa da bunlar çok uzun tamlamalar veya anlaşılması çok güç kelimeler olmadıkları için metnin dilini de ağırlaştırmazlar. Dolayısıyla eserin dilinin yazıldığı dönem ve muhtevası dikkate alındığında oldukça sade olduğu görülür. Âyînezâde’nin şerhi ile karşılaştırıldı ̆̆ında bu çalışmaya konu olan metnin dil bakımından sadeliği daha da net bir şekilde ortaya çıkar.

\section{Şerhin nüshaları}

Çalışmamıza konu olan bu şerhin şu an için elimizde dört nüshası mevcuttur:

1-) Süleymaniye Kütüphanesi Ali Nihat Tarlan Bölümü 137/2 (34 Sü-Tarlan 137/2):

Yukarıda da tanıtılan bu yazmanın 1b-89a varakları arasında Nüzhetü’l-‘uşşak, 89b-96b varakları arasında da Şerh-i Kasîde-i Rüsûhî yer almaktadır. Şiirin şerhe başlandığı sayfada herhangi bir başlık yer almamakta, başlık amacıyla sadece sürh ile "Rüsûhı̂" ibaresinin yazıldı̆̆ı görülmektedir. Şerhin bittiği 96b'de de tamamlandığını gösteren "temme" kaydı haricinde bir kayıt yoktur. Şerh, talik hatla yazılmış olup her sayfada 13 satır mevcuttur. Fizikî özellikleri yazma hakkında yukarıda verilen bilgilerle aynıdır.

\section{2-) Milli Kütüphane Yazmalar Koleksiyonu o6 Mil Yz A 2581/8}

202x147, 155x90 mm. boyutlarındaki bu yazma nesih hatla yazılmış olup toplam 160 varaktır. Her sayfada 17 satır vardır. Yazma, sırtı kahverengi meşin, ebru kâğıt, mukavva bir cilt içerisindedir. Söz başları kırmızı, yapraklarının bazıları rutubet lekelidir. Yazmada dokuz farklı eser mevcuttur. Şerh-i Kasîde-i Rüsûhî, yazmanın 148a-153b sayfaları arasında yer almaktadır. Eser yazmanın kataloğunda Şerh-i Kasîde-i Rüsûhî Efendi şeklinde kaydedilmiştir. Şerhin başladığı 148a sayfasının başında ise sürh ile Kasîde-i Rüsûhî Efendi şeklinde bir başlık yer almaktadır. Yazmada şiirin mısraları şerh boyunca sürh ile yazılmıştır. Şerhin sonunda da tamamlandığını ifade eden "Temmetüll-ḳaṣíde-i Rüsūhỉ Efendi raḥmetu'llāhi Te‘ālā 'aleyhi” kaydı yer almaktadır.

\section{3-) İstanbul Büyükşehir Belediyesi Atatürk Kitaplı̆̆ı OE Yz 684/1}

200x125, 140x65 mm. boyutlarındaki bu yazma toplam 160 varaktır. Yazmada beş farklı eser kaydedilmiş olup eserlerde kullanılan yazılar da farklılık göstermektedir. Şerh-i Kasîde-i Rüsûhî, yazmanın 1b-6a sayfaları arasında yer almaktadır ve nesih hatla yazılmıştır. Her sayfada 21 satır 
The commentary that Küçük Hâfiz Mustafa Efendi wrote on the poem of Süleyman Rüsûhî from Sofia: Şerh-i Kasîde-i Rüsûhî / E. Taştan (pp. 439-454)

vardır. Şerhin başladığı 1b sayfasının hâşiyesinde Rüsûhînnin şiirinin metni de farklı bir yazı ile kaydedilmiştir. Şerh metninde şiirin mısralarının ve alıntı yapılan Arapça ibarelerin üzeri sürh ile çizilmiştir. Şerhin sonunda tamamlandığını ifade için şu ibare yer almaktadır: "Temmetü’r-risālete sene selāsūne ve mi'e ve elf 'an Derviş Aḥmed bin Muḥammed el-Ḳādiri gaafera'llāhü lehü.” Buna göre bu nüsha 1130/1717-18 senesinde Dervîş Ahmed bin Muhammed el-Kâdirî tarafindan istinsah edilmiştir.

\section{4-) Milli Kütüphane Yazmalar Koleksiyonu o6 Mil Yz A 5221/3}

200x130, 140x83 mm. boyutlarındaki bu yazma nesih hatla yazılmış olup toplam 144 varaktır, ancak bazı varakları eksiktir. Kenarları kahverengi meşin olan, şemseli siyah meşin bir cilt içerisindedir. Söz başları kırmızıdır. Her sayfada çoğunlukla 21 satır vardır. Yazmada beş farklı eser vardır. Şerh-i Kasîde-i Rüsûhî, yazmanın 55b-59b varakları arasındadır ve katalogta sehven kendinden önce gelen eserin adıyla, Risâle fi hakkı'r-revafiz olarak kaydedilmiştir. Halbuki tam adı Risāletün fï hakḳı'rrevāfiż̀'l-merdūdīn olan bu eser, Şerh-i Kasîde-i Rüsûhî'den farklı bir eserdir ve şerhe konu olan şiirin sahibi Süleyman Rüsûhî tarafından Rafizîlikle ilgili olarak kaleme alınmıştır. Muhtemelen kataloğu hazırlayanlar, şiirin Rüsûhîye ait olması dolayısıyla Küçük Hâfız Mustafa Efendi’nin şerhini de Rüsûhî’nin bu eserinin devamı gibi düşünmüşler ve o şekilde kaydetmişlerdir. Şerhin bu nüshasının sonunda tamamlandığını gösteren "Temmetü’l-makāale" şeklindeki bir ibareden başka herhangi bir kaylt yoktur.

\section{METIN}

\section{Ey ki ‘ālemden bुaber-dārum déyen dünyā nedür}

'İnde'țțā’ife bu kāināt meẓāhir-i esmā vü ṣıfātdur. Meșelā insān ve ḥayvān ve ma‘ādin ve nebāt olmasa Ḥaḳk’uñ hālıḳıyyeti ve rāzıḳıyyeti ve sā’ir kemālātı neden ma'lūm olurdı ve ḩalḳ 'irfān-ı İlāhi'’den maḥūm ḳalurlar idi. İmdi dünyā mezra'a-i uhrā olduğından mā'adā bir şunuñ gibi 'aẓīm ma'nādan kifāyetdür, gaflet olunmaya.

\section{Bu günüñ yarını bilmezseñ déye dün yā nedür}

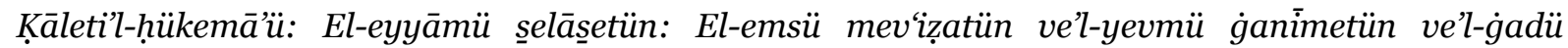
muhāțaratün ${ }^{2}$. Ems mev'iẓa olmaguuñ ma'nāsı budur ki eger ol gün 'amel-i șāliḥa makrūn olup taḳarrübe bādī ve maǵfiretüñe hādi olursa devlet senüñ. Ve eger ma'ṣıyete merhūn olup Cenāb-ı

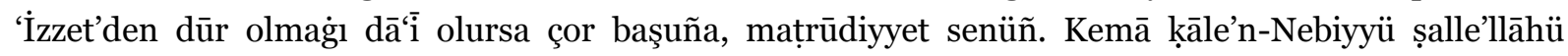
'aleyhi ve sellem: Meni’stevā yevmāhü fe-hüve mag்būnün ve men kāne emsehü hayran min gadihi fehüve mel'ūnün', ey mațrūdün 'an dereceti'l-i'tibār'4. Ve yevm ganīmet olmagiuñ ma'nāsı oldur ki yevmi cedīde duhūl ehl-i ḳubūruñ devr-i Ādem'den tā nefh-i șūra varınca isteyüp hergiz ḥuṣūle mevșūl olmayan temennālarıdur ki ḳāle'llāhü Teâāâ: Rabbenā ehricnā na'mel șāliḥan 5 anlara vérilmeyüp saña vérilmişdür. Meșelā nevm küçük ölümdür. Zīrā uyhuu göz görmez, ḳulaḳ işitmez, el țutmaz, dil söylemez ve bi'l-cümle ḳuvāsı işlemez olmaḳdur. Çünki böyle olduñ, eger uyanmasañ hemān öldüñ idi. Çünki uyandıñ, ehl-i kubūruñ bunca zamāndan berü isteyüp bulımaduḳları devleti rāygān bulduñ, 'aceb furșat ve özge ganīmet degül midür? Neden bildüñ ki bir dahıı bulasun? Sa'y eyle ki maḳbūl-i

2 Hakîmler şöyle demişlerdir: "Günler üçtür: Dün, öğüttür; bugün, ganimettir; yarın ise tehlikedir."

3 Hz. Peygamber 'Aleyhi's-selâm şöyle buyurmuştur: "İki günü eşit olan ziyandadır; dünü yarınından hayırlı olan lanete uğramıştır." (Aclûnî 1421: 274, 2406. Hadis)

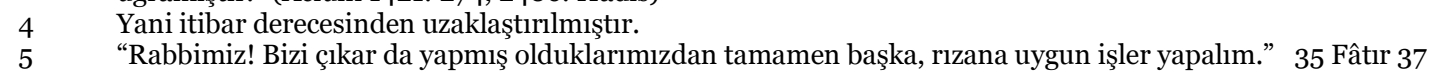


Ḥażret olasun. Zīrā Bārī Te‘ālā bir kerre lā İlāhe ille'llāh démek, dünyā țolusı altundan yégrekdür déyü buyurur. Hayșü ḳāle: Fe-len yuḳbele min ehadihim mil'ül-arżı żeheben ve-levi’ftedā bih ${ }^{6}$. İmām Kuşeyrì Ḥażretleri kuddise șırruhü küffārdan dünyā tolusı zer mü’minlerüñ zerre kadar i̇mānına berāber degüldür déyü tefsīi eyler. Ve gad muhāțara olduğınuñ ma'nāsı eyledür kim bilmezüz șabāḥa çıḳar mıyuz çıḳmaz mıyuz. Çıḳdığumuz taḳdīrce sa'ìd mi çıḳaruz, şaḳi mi, merdūd mı maḳbūl mi manșūb mı ma'zūl mi, hațar-ı 'azịim degül mi? Tedārüki lāzım emr-i mühimdür, himmet olına.

\section{On sekiz biñ ‘ālemi garḳ eyleyen deryā nedür}

Bunca 'ālemi hạāvì olan deryā Allāhü Te'ālā'dur. Kemā kạale fī Kitābi'l-Mecīd: İnnehü bi-külli şey’in muhit ț7.

\section{Yā o deryāyı yudan māhīçe-i ṣug̀rā nedür}

Bu baḥr-ı bī-pāyānı yudan ḳalb-i insān-ı kāmilü'l-ižāndur ki hadīṣ-i ḳudsīde mežkūr ve kütüb-i

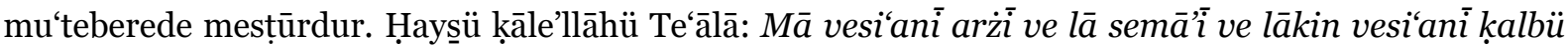
'abdiye'l-mü'mini ${ }^{8}$.

\section{Ādemi tecrīḥ ü tercị̣ eyleyen kimler-dürür \\ Kandan ihrāc étdiler İblīs’i istiṣnā nedür}

Ādem'e ța‘n édenler şeyțāna tābi‘ olup e-tec'alü fīhā men yüfsidü fīh $\bar{a}^{9}$ déyenlerdür. Tercịh édenler hịmete vāḳıf olup rütbe-i Ādem’i bilenler ve kerāmetine muțali' olanlardur. Ba‘de zaālik Ādem'e secde ile me'mūr olan meleklerden ve şeyțān-ı cinnīlerden olup müsteșnā, müsteșnā minhde dāhnil degül iken istisnā fașị̣ olmaz. Ve erbāb-ı tefsīiüñ şimdiye degin olan taḥrīleri șaḥị̣ olmayup şifā'-i 'alīl ve tesḳ̂i-i galīl étmedügi hafî̀ degüldür, te'emmül ḳl. El-cevāb: Allāhü a'lem ța'n édenlere re’ís, İblīs-i pür-telbīs ve secde ile me'mūr olunanlar dahı ța'n édenler ve zecren lehüm secde ile emr olunmışlar olıcak. İblis muṭlakāa țā'atlardan ihrāc olunmış, melek olup olmaması makṣūd olunmamışdır. Fe-'alā hāzaā İblis̄'üñ secdesi bi’ṭ-ṭariḳıı'l-evlā lāzım gelmiş söz yérin bulmışdur. Ve anlar ki li-'umūmi'l-lafạı ve 'ademi'lmuhașșıșı meḳūlün lehüm cümle-i melā’ikedür démişlerdür. Estekberte em-künte mine'l-ālin ${ }^{10}$ āyetinüñ Keşşāf, K̦āżìi, Kemāl Paşa-zāde, Ebu's-Su'ūd raḥimehümu'llāhü Te‘ālā muhașșıṣ oldugìndan zühūl ve [mā min] 'âmmin [illā ve kad] husșșa minhü'l-ba‘żu $u^{11}$ ḳabīlinden oldugindan șoñra gayrılaruñ dahı hurūcindan gufūl üzre olmışlardur, gaflet olunmaya.

\section{Cins ü fașlı nev‘ ü așlı bir iken ey bü'l-'aceb}

İşāretün ilā ḳavlihi Te‘ālā: Halaḳa-küm min nefsin vāḥidetin²12. Ve ilā ḳavlihi 'Aleyhi's-selām: İnne Rabbe-küm vāhiidün ve ebāküm vāḥidün${ }^{13}$. Fe-yecūze en yerādü mine’l-ebi Ādem 'aleyhi’s-selāmü ve en yerādü minhü'l-'aḳlı'l-evveli ya'nì rūḥu'n-Nebiyyü'l-ekmeli14.

\section{Arasında bunlaruñ bu deñlü bu ġavġā nedür}

6 "Evet, inkâr edip de kâfir olarak ölenler var ya, onların hiç birinden kendini kurtarmak için dünya dolusu altın verecek olsa dahi asla kabul edilmeyecektir.” 3 Âl-i İmrân 91

"Muhakkak ki O (Allah) her şeyi kuşatmıştır.” 41 Fussilet 54. Yazmada "innehü” yerine "ve hüve” ibaresi yer almaktadır.

"Ben göklere ve yere sığmam, fakat mümin kulumun kalbine sığarım.” (Aclûnî 1421: 229, 2256. Hadis)

"Orada fesat çıkaracak ve kan dökecek birini mi yaratacaksın?" 2 Bakara 30

“Büyüklük mü taslıyorsun, yoksa ululardan mısın?” 38 Sâd 75

Her umûmî kâidenin bir istisnası vardır.

"O sizi bir tek nefisten yaratmıştır.” 39 Zümer 6

"Hz. Peygamber Aleyhi's-selâm şöyle buyurdu: Muhakkak ki Rabbiniz birdir ve babanız da birdir.” Beyhakî 1423/2003: 132 (7. Cild), 4774. Hadis.

14 Âdem aleyhisselamdan ve akl-1 evvelden yani Hz. Peygamber’in ruhundan bahsedilmiş olması caizdir/mümkündür. 
The commentary that Küçük Hâfiz Mustafa Efendi wrote on the poem of Süleyman Rüsûhî from Sofia: Şerh-i Kasîde-i Rüsûhî / E. Taştan (pp. 439-454)

Vechi'l-ihntilāf beyne'l-eslāf ve’l-ahlāf teḳābül-i esmā’-i ìlāhỉ ve iḳtiżā’-i isti‘dād-ı gayr-ı mütenāhīdür ve lehü.

\section{Bunlaruñ hep feyżi bir yérden gelürken lā-cerem \\ Kimi ‘ārif kimi ‘āmī kimisi şeydā nedür}

‘Alā ḥasebi’l-isti‘dād ve muḳteżā-yı nihādlarıdur.

\section{Kiminüñ hurşìd-i ‘ālem zerre gelmez ‘aynına}

Kimini her şeyde ḥayrān eyleyen āyā nedür

Ba‘żı ekābirüñ keyfe a'rifu şey’en ve ente fīhi ${ }^{15}$ dédükleridür ve's-selām.

\section{'Āşıḳa ma'şūḳ artıḳ rāğıb iken pes yine \\ Anda bu deñlü temennā bunda istig̀nā nedür}

\section{Şirk ile īmān gelmez bir yére lā raybe fỉh \\ Ehl-i İslām'uñ dilinde lā nedür illā nedür}

Lā ve illā ehl-i taḳlīid dilinde olur, ehl-i tevhịid dilinde olmaz. Kemā ḳāle'ş-şā‘irü:

Düyi şirk-est ez-ū bü'gžer muvaḥhịid bāş u yektā şev

Vücūd-ı mā-siva'lāh rā be-lā bü'gzār u illā şev ${ }^{16}$

Ve menşeün zāalike ḳavlühü 'Aleyhi's-selām lā yedhulü'l-īmāne fi'l-mīzāni'17. Șu'ūd-1 a'māle intihā, Sidretü'l-müntehādur. Ve'l-mízānü 'indeha ${ }^{18}$. Ammā ỉmān mā-verā-yı 'arş-1 Raḥmān'dur, mīzāna inmez, farażā indügi taḳdīrce dahı mevāzīni bulunmaz. Kâale 'Aleyhi's-selām: Lev vużı'at Là İlāhe ille'llāhü fï kiffetin ve's-semāvātü’s-seb'a ve ‘āmir-hünne ve'l-arżūne's-seb'a ve ‘āmir-hünne fï kiffetin uhrā le-mālet Là İlāhe ille'llāhü ileyhinne ${ }^{19}$. Pes Lā ìlāhe ille'llāhuñ mīzāna girmedügi mevāzini olmadug̀ı içün imiş. Bu cümle fehimhü eshel ba‘żı kümmel buyurduḳlarıdur ki ìmān olan yérde şirk olmaz, şirk olan yérde ỉmān olmaz. Anuñ-çün mīzāna gelmez ve bi'l-cümle muvaḥhid ile muvaḥhad var iken ikilik muḳarrer olup tevḥid mutașavver olmaz. 'Ulemā-yı rüsūmuñ ba'de’n-nefy ve išbāt sübūtda ekīd olur dédükleri 'ale'l-1ṭlāḳ sedīd olmadığı bundan ma'lūm olur. Ve'l-ḥāṣll vaḥdet-i vücūda kâa’il olmayanlarda tevḥid müşkil olur. Ve ol muvaḥḥidler ki ke'l-ḥadīdi'l-muḥmāti 'alā țarị̂̀ı’t-tagilībi ev ke'ş-şemsi ma‘a'l-kevākibi min süneni'l-iżmiḥlāl vaḥdete mā’il olmışlardur, bāṭıldur. Ve ke’l-baḥri ve emvācihi déyenler dahı gaayr-ı kāmildür. Zīrā mümkin, vācib olmaḳ muhāl bunlar șādık olmaḳ ne ị̣timāldür, gaflet olunmaya. Ve’s-selāmü 'alā tābi‘i’l-hüdā.

\section{Eyleyüp Ḥaḳk’’a tevekkül ḳul olan Mevlāsına \\ Bugün içün gușṣalanmaḳ yā gaam-ı ferdā nedür}

Bu beyt, tevḥīd-i ef’ālden ‘ibāret ve üstündeki beytüñ te’viline işāretdür.

Sen onun içindeyken ben onu nasıl bileyim?

"İkilik şirktir ondan geç, muvahhid ol ve (böylece) eşsiz ve benzersiz ol. Allah’tan başka her şeyin varlı̆̆ını "lâ" ile terk et ve "illâ" ol." (Dîvân-ı Seyyid 'İmâdü’d-dîn Nesîmî 1972: 280).

Peygamber Aleyhisselâm şöyle buyurdu: “İman mizana girmez." Hadîs-i şerîf

Ve mizan onun katındadır.

Peygamber Aleyhisselâm şöyle buyurdu: "Lâ ilâhe ille'llâh bir kefeye, yedi kat gök ve yedi kat yer de bir başka kefeye konulsa, Lâ ilâhe ille'llâh daha ağır basar.” (Müsnedü Ebī Yalā El-Mevslli 1404-1410/1984-1990: 528), El-cüz'ü'ś-s̄ānī, 1393. Hadis.) 


\section{Söylemek görmek işitmek añlamak bilmek nedür}

Yā bu evṣāf ile mevṣūf ol dür-i yektā nedür

İşāretün ilā ḳavlihi 'Aleyhi’s-selām: Men 'arafe nefsehü fe-ḳad 'arefe Rabbehü ${ }^{0}$. Zīrā eger senüñ görmek ve işitmek ve sā’ir havāssuñdan Cenāb-ı Pāke fi’l-cümle müşterek olmañ olmasa Allāhü Te‘ālā Ḥażretlerinüñ bu evșāf ile ittiṣāfını neden bilürdüñ ve istidlāline ne țarìị-ile yol bulurduñ ve bu țavr-ı cemīle Halaka'llāhü Ādeme 'alā șūratihi ${ }^{21}$ ḳavi delīldür, tescīl oluna. Ve ol dürr-i yektā nüsḩa-i 'ālem, belki ‘ālemden dahı a'ẓam olan Ādem’dür ki Ḥāıłı̣-ı Şīāzī buyurur, beyt:

Dūş dīdem ki melā'ik der-i meyhāne zedend

Gil-i Ādem be-siriştend ü be-peymāne zedend ${ }^{22}$

Eyle ta‘bīi édüp ba‘żı merātibin tefsīir eylemişdür ki dūş, 'ālem-i gaybdan 'ibāretdür. Melāỉk, hālıḳıyet ve rāzıḳıyyet gibi șıfāt-ı mücerrededen kināyetdür. Meyhāne ḳapusın ḳaḳımak, mezāhir istemek olup șıfāt-ı Ḥaḳk’ı ve nu'ūt-ı halḳı ḥāvi olan kevn-i cāmi'den her biri ḥiṣṣe-dār olup maẓhar-ı İlāhiyyeye hiżmetkār olduḳlarını iş‘ār eyleyüp peymāne zedend ile aña işāret eylemişdür. Li'llāhi derru'l-ḳā’ili²3. Bunuñ gibi kelām-ı belìiguñ ḳā’iline cebr isnād édenler ye‘lemu'llāh cāhildür, 'āleme ma'lūmdur.

\section{Benden evvel bildügin étmiş éden olmış olan}

\section{Bunda vü anda benümle olunan da'vā nedür}

Bu mes'ele ḳażā ve ḳader mes'elesi ve cebr-i șırf gāàilesidür. Gerçi nā-şenīdedür ammā pūşīde buyurulmaya ki hịmet üçdür: Mechūle ve meskūte ve malūmedür. Ḥikmet-i ma'lūme şer'an ifşāsı cāìz olanlar ve fā’idesi 'umūm üzre bulunanlardur. Ḥikmet-i mechūle, enbiyādan bile mektūm olanlardur. Meșelā ma'ṣūmlaruñ ba‘żı emrāż-ı hā’ile ile ibtilāsı gibi. Ḥikmet-i meskūte 'inde'l-ḥavāṣṣ bilinmesine menāṣ olup lākin beyne'l-'umūm söylenmesi memnū' ḳlınanlardur ki șadedinde oldug̉umuz ma‘ānì-i daḳịka ve niḳât-ı enịḳa gibi. Kul küllün min 'indi'llāhi24 mażmūnından ḳopar, cebr-i șırfı ohşşar ma'nālardur. Ammā fī nefsi'l-emr, cebr-i șırf degül, cebr-i mutavassița bile kạàil degülüz. Zīiā ḳader ḳażāya, ḳażā 'ilmu'llāha, 'ilm ma'lūma tābi' olduġı ekābir-i 'ulemā'-i ümmet ve kümmel-i șuleḥā-yı ehl-i sünnet mā-beyninde şāyiđdür. Zīinā 'ilm șıfātdan, zāât ma'lūmātdandur. Pes Allāhü Te'ālā bizüm vücūd-ı zāhirümüzden evvel vücūd-ı 'ilmīmüzüñ isti'dādına nazaran bildügin étmekden zulm lāzım gelmez; nihāyeti 'adl étmiş olur, hilāfın étmekden hiikmete halel gelür. Belki Ḥażret-i Allāh'uñ 'ilmi vāḳı'a muțābık olmış ma'lūmuñ isti'dādına i'țā étdi ise eyle bilmiş ve bildügine göre 'amel ḳılmışdur. Ve bu mes'ele mevcūd ma'dūm ve ma'dūm mevcūd olmaz dédükleri muḳaddimei șahịhhaya mebnidür ve māhiyyet gayr-ı mec'ūle olmaḳ aṣlından münteşidür. Zīiā māhiyyet-i a'yān-ı șābite, șuver-i 'ilmiyye-i İlāhiyye'dür, mec‘ūle olmaġa gayr-ı kāāildür ve orada olan levāzımı dahı mec'ūle degüldür. Bizüm ihtiyār-ı cüz'īmüz dahı anlardandur, mec'ūle olmak muhāldür; cebr-i șırf degül, cebr-i mutavassița bile ḳațā mecāl yoḳdur. 'Ulemā-yı rüsūm bundan gaāfil, ba'żı umūr mā eșābeke min ḥasenetin fe-mine’llāhi25 mażmūnı taḥtında dāhildür. Zīiā bizüm ketm-i 'ademden vücūda gelmemüze aṣlā mükāfāt mümkin degüldür; bu ḳanda ḳaldı bir gaayrı ḥaseneyi dahı muḳtażi ola. İmdi her ne ḳadar iyilik var ise cümlesi tefażżul-ı İlāhỉ ve luṭf-ı maḥż-ı gayr-ı nā-mütenāhīdür. Ve

\footnotetext{
$20 \quad$ "Kendini bilen Rabbini bilir." Hadîs-i Şerîf

"Allah Âdem’i kendi sureti üzere yaratmıştır.” (Sahîh-i Müslim 1421/20oo: 1234, Hadis no: 2841)

"Dün gece meleklerin meyhanenin kapısını çaldıklarını gördüm. Âdem’in balçığını yoğurdular ve kadehe koydular." (Dîvân-ı Hâfiz 1397: 247, 184. Gazel/1. Beyit).

Aşk olsun (aferin) sözü söyleyene/inanmıș, aklı yatmıș olana!. [Lafzen: Sözü söyleyenin başarısı Allah’tandır.]

"De ki: Hepsi Allah katındandır." 4 Nisâ 78.

"Sana gelen iyilik Allah'tandır." 4 Nisâ 79
} 
ba‘żı umūr ve mā eșābeke min seyyi’etin fe-min nefsike26 hịiṭasına nāzildür. İmdi her seyyi’e elbette bir ma'ṣıyet mukāābelesinde bizüm kesbümüz sebebi iledür, ḳul küllün min 'indi'llāh27'a müzāhim degüldür; kesb gümrāhuñ, ìcād Allāh'uñdur. Gerçi bu maḥalde söz çoḳdur, ammā yaḳinen baña ma'lūmdur ki aṣlā ve ḳațā cebr yoḳdur. Lākin verā-yı șuverden nāẓır olan ḍịkụ'l-bașaruñ naẓarı be-her ḥāl sāye-i 'adl üstine düşer, giderek cebre çıḳar, bi'l-külliye cebr ḳalḳar. Nitekim kātibüñ yazadurduğı kāg̀ıduñ üstindeki mūr, ḳalemi yazar görür, yed-i kātibden ve yedüñ kalb-i kātibe irtibāṭndan ve kalbüñ ma'lūma ittibā'ından bì-ḩaberdür. Bu beyān cümleden eshel ve etemdür, şimdiden șoñra añılmazsa fehmüñ müttehemdür. Her kim ki 'ayn-ı sābitesinde mü'min ola, hātimesinde emīn olur. Beyne'l-bed’i ve'l-ḩatm andan z̦āhir olan küfr ü 'ișyān 'irfānına ziyān eylemez. Kemā üşīiü ileyhi bi-

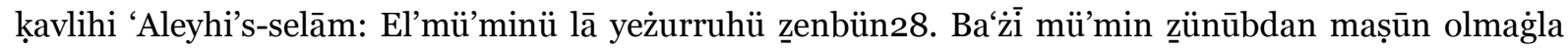
mużarr olmaz ve ba‘żì mü’minüñ zenbi tevbesi ḳabūl olunup seyyi’ātı ḥasenāta tebdīl olunmak içün każāà olunmış 'ayn-ı sāaitesi mü’min bulunmışdur. Ādem 'aleyhi’s-selām ve ol ḥażretüñ ḳademinde bulunan evlād-ı kirām gibi zenb żarar vérmez, küfr dahı kezālik hatm ü bed'e muțābık olur. Beyne’lbed'i ve'l-ḩatm andan șudūr bulan ḥasenāt u ị̣sān mehebb-i riyāḥda perdesüz bulunan şem'-dān gibi münțafī vü bī-nişān olur ve bi'l-cümle 'ayn-ı șābitesinde şeḳāvet olan ḳābil-i hidāyet olmaz. Kezāalik kāle'llāhü Te‘ālā: Ve lev şā’e le-hedāküm ecma'īn29. Ve lākinnehü lem-yeşā'ü lā metā'un hidāyeten likülli3o. Zīiā Hạk ḳ’uñ meşiyyeti 'ilmine tābi', 'ilmi ma'lūmına tābi'dür. Ba‘ziì ma'lūm ḳābil-i hidāyet olur ve ba‘żī olmaz. Kemā kāale’ş-şāiirü:

Bārān ki der-lețāfet-i țab'-eş hilāf nīst

Der-bāg lāle rūyed ü der-şūre-būm hăas ${ }^{1}$

Ve'l-ḥāṣıl her nesne kendü kümūninde olanı ı̣hār eyler. Görmez misüz ki her nuṭfe atası şeklini yetürmez ve hergiz emrūd ag̉acı elma bitürmez. Beyt:

Ebr eger āb-ı zindegī bāred

Hergiz ez-şāh-ı bīd ber ne-horīi32

Yevm-i ḳażāda sırr-ı ḳader mekşūf olup hīç kimse Allāhü Te‘ālāya "Yā Rab niçün beni şöyle étdüñ, böyle étmedüño” déyübilmez ve çūn ü çirāya yol bulmaz. Fe-li’llāhi’-hüccetü’l-bāligatäü33. Bunda dahı sırr-ı ḳadere vāḳıf olanlardan bir ḩațā șādır olmaz. Șādır olsa nefsini melāmet eyler. Anuñ-çün Ādem 'aleyhi's-selām Rabbenā zalemnā enfüsenāa 34 déyü 'özrr eyler. Cāhil olanlar nefsini tenzīh eyleyüp hațāyı tekrārlar. Anuñ-çün İblīs 'aleyhi'l-la'ne ene ḩayrun minhü35 déyüp Cenāb-ı Pāk’i tahțı'e étmek ister. Ḥaḳḳ’ı derk étmez, 'ișyānı zāāîürr, gitmez. Ammā ḳuṣūr-ı Ādem 'alā vechi'l-'us̄ūrdur, anuñ-çün ma‘žūrdur. Ḥadd-i žātında munṣıf-ı muḳteżā-yı neş’eti olduğına mu'terif Rabbisinde ḳațāa zulm olmaduġına 'ārifdür. Ḳābil-i hidāyet, muntaẓır-ı raḥmetdür. Lisānü'l-ġayb ve tercümān-ı lā-reyblük ile mülaḳkab olan Ḥāfıẓ-ı Şīīāỉnüñ

\footnotetext{
"Başına gelen kötülük ise nefsindendir.” 4 Nisâ 79

"De ki: Hepsi Allah katındandır." 4 Nisâ 78.

Hz. Peygamber (A.S.)’n sözü ile ona işaret edildiği gibi: "Mü’min kula günah zarar vermez.” (el-Münâvî 1422/2001: 273, Hadis no: 5042).

"Allah dileseydi hepinizi doğru yola iletirdi." $16 \mathrm{Nahl} 9$

Ancak o herkes için bir hidayet faydası/yararlanması istemedi

“Tabiatının letafetinde herkes müttefik iken, yağmur bile bağda lale bitirir, çorak yerde çerçöp.” (Gülistan 1379: 35, 4. Hikâye)

“Bulut ölümsüzlük suyu yağdırsa bile söğüt dalından meyve yiyemezsin (alamazsın).” (Gülistan 1379: 33, 4. Hikâye)

"Kesin delil ancak Allah'mndır." 6 En'âm 149

"Ey Rabbimiz! Biz kendimize zulmettik." 7 A'râf 152

"Ben ondan daha üstünüm." 38 Sâd 76 / 7 A'râf 12
} 
Der-kūy-ı nìk-nāmī mā-rā güzerer ne-dādend

Ger tū ne-mī pesendī taġyìr kun ḳażā-rāâ 36

dédügi ve ekșer ebyātında cebr-i șırf șūretinde gösterdügi sözleri bu vādīdendür. Ḥikmeti budur ki henūz işāret olundugi gibi günāh yā 'afv olunmaḳ içündür, șāhiibi zemm olunmaz; veyā 'uḳūbet olunmaḳ içündür, șāhibi müsteḥaḳḳ-ı melāmet olur. Ammā 'ālem-i teklīfden bu iki zenbüñ mā-beynini

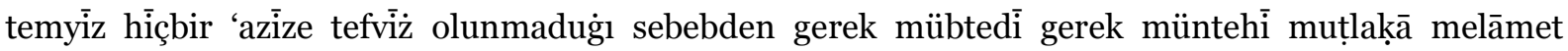
menhīdür, cā’izdür ki evvelki ḳabīlden olup maḳbūl-i Hudā’ya la'net étmekden vahş̧et eylerler. Edeb-i şerī'at-i mürselīn ve țariḳat-i evliyā-yı kāmilīn budur. Țālib-i dīn iseñ șaḳın ve eger 'Ömer Hayyām’uñ, rubā'ì:

Men mey horem ü her ki çü men ehl buved

Mey horden-i men be-nezd-i ū sehl buved

Mey horden-i men Ḥaḳ be-ezel mī dānest

Ger men ne-horem 'ilm-i Hudā cehl buved ${ }^{37}$

dédüginden murādı eger Ḥāfız-ı Şīrāzi gibi "'ỉlm, ma'lūma tābi'dür; süci içmekde șuç benümdür, 'ayn-i șābitem iḳtiżā étmişdür." démek ise Ṭūsī'nüñ anı, beyt:

Goftī ki güneh be-nezd-i men sehl buved

În nükte ne-gūyed ān ki ū ehl buved

‘̇̀m-i ezeli 'illet-i 'ișyān kerden

Nezd-i 'uḳalā zi-gāayet-i cehl buved $3^{8}$

ḳavliyle reddi fāsiddür. Ve illā eger şeyțān gibi cebre ḥavāle étmek ise Ḥażret-i Fārūḳ’uñ raḍya'llāhü 'anh sārıḳı reddi gibidür, tamām vāriddür ve bi'l-cümle bunuñ gibi umūra fi'l-cümle şu'ūra erbāb-1 taṣfiyyeye hizizmet lāzımdur. Ve illā terk étmek evlā, belki mühimdür, ve’llāhü a‘lem bi’ṣ-ṣavāb.

\section{Hāme-i șun'a hațā nisbet olunmazsa eger}

Bunca yañlışlar bu ‘ālem defterinde yā nedür

Ḳāle ba‘żu’l-vāḳıfı: El-esrāruhü āyātühü.

Lā yünkirü'l-bāṭllu fī țavrihi

Fe-innehü ba‘żu ẓuhūrātihi³9

Ba‘żı mevțin ḩafā iḳtiżā eyler, yoḩsa defter-i Ḥaḳ’da ḩațā neyler?

Perde-i pindāruñı ḳaldırmayınca aradan

Ey Rüsūhī bilemezsüñ bunlara ma'nā nedür

\footnotetext{
36 Bizi iyi ad (kazanma) diyarına geçirmediler. Beğenmiyorsan kaderi değiştir.” (Dîvân-ı Hâfiz 1397: 8, 5. Gazel/7. Beyit) "Ben şarap içerim ve benim gibi her ehil olan kimsenin şarap içmesi Allah katında önemsizdir. Benim şarap içeceğimi Allah ezeli ilmi ile bildi. Ben şimdi içmeyecek olsam Allah'ın ilmi cehl olur.” (Yâr Ahmed bin Hüseyn Reşîlî-i Tebrîzî 1367: 101).

38 "Benim nazarımda günah önemsizdir, diyorsun. Bu sözü ehil olan kişi söylemez. (Allah’ın) ezelî ilmini isyanın sebebi yapmak/saymak, akıllı kişilerin nazarında cehaletin fazlalı̆̆ından olur/kaynaklanır.” Yâr (Yâr Ahmed bin Hüseyn Reşîdî-i Tebrîzî 1367: 101). (Yâr Ahmed bin Hüseyn Reşîdî, Ömer Hayyâm’ın rubailerini konu alan eserinde Hayyâm'a ait olan yukarıdaki rubai için düştügü dipnotta, metinde Nâsır-ı Tûsî̀ye ait olarak gösterilen bu rubainin Nâsır-1 Tûsî yanında Baba Efdal-i Kâşânîye de nisbet edildiğini de belirtir.)

39 (Meseleye) vâkıf olanlar dediler ki: Onun sırları âyetleridir. Bâtıl bunu kendi mevkiinde (esasında) inkâr etmez. Muhakkak ki (inkâr ettiği) bazı zuhurâtlarıdır.
} 
The commentary that Küçük Hâfiz Mustafa Efendi wrote on the poem of Süleyman Rüsûhî from Sofia: Şerh-i Kasîde-i Rüsûhî / E. Taştan (pp. 439-454)

Temmetü’l-ḳaṣide-i Rüsūhī Efendi raḥmetu'llāhi Te‘ālā ‘aleyhi.

\section{Sonuç}

Küçük Hâfız Mustafa Efendi’nin 16. asır şairi Sofyalı Süleymân Rüsûhî’nin şiiri için yazdığı bu şerh, gazel, kaside, şathiyye gibi kısa metinlerin şerhi geleneğinde dikkate değer bir yere sahiptir. Enderûn'un Seferli Koğuşu'nda yetişen ve iyi bir eğitim aldığı anlaşllan müellifin söz konusu şiiri muhtasar bir biçimde şerh ettiği, bazı beyitlerin şerhinde birkaç cümleyi geçmediği görülür. Ancak birkaç beyitte açıklamaların geniş tutulduğu ve konunun etraflıca ele alındığı da dikkati çeker. Müellif, genel olarak muhtasar bir şerh kaleme almasına rağmen eserini hazırlarken oldukça fazla sayıda kaynaktan faydalanmış ve bunlardan iktibaslarda bulunmuştur. Şerhde dinî ve tasavvufi eserlerden yapılan iktibaslar yanında edebî metinlerden yapılan iktibaslar da dikkati çeker. Dil ve üslup özellikleri bakımından orta nesir türü eserler içinde değerlendirebileceğimiz Şerh-i Kaside-i Rüsûhî’nin, muhtevası itibarıyla benzer tasavvufî metinleri anlamada önemli kaynaklardan biri olacağı muhakkaktır.

\section{Kaynakça}

Aclûnî (1421), İsmâil b. Muhammed, Keşfü'l-hafâ ve müzīlü'l-ilbâs, Dımışk: Mektebetü'l-'ilmi'l-hadîs.

Beyhakî (1423/2003), Ahmed b. Hüseyin, el-Câmi‘u li-şu'abi'l-îmân, Su'ûdî Arabistan, Mektebetü’rrüşd.

Ceylan, Ömür (2000), Tasavvufí Şïr Şerhleri, İstanbul: Kitabevi Yay.

Dîvân-ı Hâfiz (1397), Haz. Halîl Hatîb Rehber, Tahran: İntişârât-ı Safî Alişâh.

Dîvân-ı Seyyid ‘̇̇mâdü’d-dîn Nesîmî (1972), Haz. Hamîd Muhammedzâde, Bakü: Âzer Neşriyat.

Gülistân (1379) , (Fârisî-İngilisî), Şeyh Muslihu'd-dîn Sa‘dî-i Şîrâzî, Haz. Seyyid Kemâl Hâc Seyyid Cevâdî (İngilizceye tercüme eden: Francis Gladwin), Tahran: İntişârât-ı Beyne'l-milelî-i ElHüdā.

el-Münâvî (1422/2001), Muhammed Abdü'r-ra'ûf, Feyzül-Kadîr Şerhu'l-Câmi'i’s-Sagîr, Beyrut: Dârü'l-Kütübü'l-İlmiyye, IV. Cild.

Müsnedü Ebì Ya lā El-Mevsılî (1404-1410/1984-1990), Haz. Hüseyin Selîm Esed, Dımışk-Beyrut.

Sahîh-i Müslim (1421/2000), nşr. Muhammed Fuâd Abdülbâkî, Suûdi Arabistan: Dârü's-selâm.

Taştan, Erdoğan (2017), "Âyînezâde Muhammed Şemseddîn-i Sirozînin "Şerh-i Manzûme-i Rüsûhî" Adlı Eseri”, Divan Edebiyatı Araştırmaları Dergisi 19, İstanbul, s.313-344.

Yâr Ahmed bin Hüseyn Reşîlî-i Tebrîzî (1367), Rubâiiyyât-ı Hayyâm (Tarab-hâne), (Tashîh: Üstâd 'Allâme Celâle'd-dîn Hümâyî), Tahran: Müessese-i Neşr-i Hümâ.

Yazar, Sadık (2011), Anadolu Sahası Klâsik Türk Edebiyatında Tercüme ve Şerh Geleneği, Yayımlanmamış Doktora Tezi, İstanbul: İstanbul Üniversitesi Sosyal Bilimler Enstitüsü.

Yılmaz, Ozan (2007), "Klâsik Şerh Edebiyatı Literatürü”, Türkiye Araştırmaları Literatür Dergisi, S. 9, 271-304. 